\title{
Malay Political Tradition: The Appointment and Succession Analysis of The Sultanate of Palembang Darussalam
}

\section{Mohammad Syawaludin 1,* (D), M. Sirajudin Fikri 2 (D), and Yulion Zalpa ${ }^{2}$ \\ ${ }^{1}$ Department of History of Islamic Civilization, Faculty of Adab and Humanities, Raden Fatah State Islamic University of Palembang, 30126 Palembang, Indonesia \\ ${ }^{2}$ Department of Islamic Politics, Faculty of Adab and Humanities, \\ Raden Fatah State Islamic University of Palembang, 30126 Palembang, Indonesia \\ * Corresponding Author: mohammadsyawaludin_uin@radenfatah.ac.id}

\section{ARTICLE INFO}

Publication Info:

Literature Review

How to cite:

Syawaludin, M., Fikri, M. S., E Zalpa, Y. (2019). Malay Political

Tradition: The Appointment and Succession Analysis of The

Sultanate of Palembang

Darussalam. Society, 7(2), 213-

232.

DOI : 10.33019/society.v7i2.108

Copyright () 2019. Owned by Author(s), published by Society

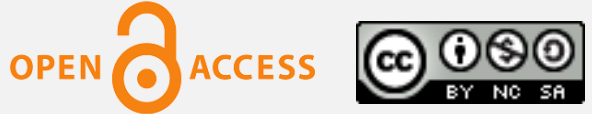

This is an open access article.

License: Attribution-

NonCommercial-ShareAlike

(CC BY-NC-SA)

Received: October 31, 2019;

Accepted: December 26, 2019;

Published: December 31, 2019;

\section{ABSTRACT}

This study aims to determine and explore how Islam and Malay as an intertwined entity influence the formation of political institutions in the Sultanate of Palembang, especially influencing the appointment and succession of the Sultan. This study is the result of qualitative research based on a literature review using interpretive analysis techniques. In the practice of Islam in Indonesia, cultural values of non-Islamic religions are maintained and practiced by Islamic entities such as practices in the replacement of the King and Sultan. A theoretical approach to society by looking at the evolution of kings approached to explain the history of state administration and the transition of power, combined with Elite; Political Culture, and Cultural Politics. The results of this study found that the system of appointment and change of power in the Sultanate of Palembang, namely the existence of its characteristics associated with a blend of Malay and Javanese culture. Differences in political culture greatly influence the process of succession that occurs. Malay culture which emphasizes more on its economy in the maritime field and Arabic symbols will be different from Javanese culture which is more agrarian and syncretic.
Keywords: Islam; Malay Culture; Palembang; Succession; Sultanate

Copyright (C) 2019. Owned by Author(s), published by Society. This is an open access article under CC-BY-NC-SA license. 


\section{Introduction}

The rapid development of studies on Islam, Malay and local traditions is as two things integrated into the social formation, especially in Indonesia. Islam as a religion that teaches various normative and humanist aspects undergoes a process of acceptance and rejection in society, whereas Malay and tradition as a particular community's identity also undergo dialectical processes in establishing conformity with Islamic teachings.

Islam, Malay and local traditions are constantly studied with scientific approaches that are generally based on ideographic. It proves the encounter of Islam, Malay and local traditions is not only understood as a teaching process but also created social, cultural, economic institutions and even political power institutions that tolerate local values. The circle of Islam, Malay, and local traditions becomes magnetism that cannot be separated from the dynamics and changes occur. Further, forming wider and dominant social formations.

The term "Malay" is not identical to a particular ethnic community or ethnic group but an entity that is flexible and resembles entity a nation and even groups of allied ethnicities that share the same religion and language. Malay is the fusion of foreign descents such as Arabic, Persian, Chinese and Indian, and other ethnic in Nusantara. Adaptation which is followed by a process of defusion can occur because of some factors such as migration and the process of settling which makes them live longer with Malay people and local tribes. The other side is embracing the same religion and using Malay in daily communication. It makes Malays have their distinct characteristics that are different from other ethnicities such as Javanese, Sundanese or Betawi. Although Malay people live in several separate areas, both on land and in water, even among them far apart, wherever they are, their language and religion are the same as the core culture of Malay's main identity. Several factors of the process can form the structure and functional "Malay" typical of other Indonesian tribes, including:

1) Trades and Ports are entry points for various activities related to commerce and power relations;

2) Marriage between Muslim migrants and indigenous women then forms a new kinship between families;

3) Expansion of political power and the decrease of the Hindu and Buddhist kingdoms influences;

4) Starting to accept orthodoxy and heterodoxy Islamic teachings marked by the presence of Sufi scholars and figh (Islamic Law);

5) The process of Islamization of native kings by Sufi scholars or Sufism experts;

6) Malay as the language of the spread of Islam and the language of instruction in Islamic educational institutions both speaking and writing (Malay Arabic with various types);

7) Sufi entities and scholars began to build new intellectual traditions within the realm of kingdoms and some even became advisors to the King or Sultan.

The factors above greatly affect the lives of people in Indonesia. Although it is difficult to prove that local traditions are not identical to Islam or vice versa, Islam is what forms the local tradition of power. Therefore, the practice of Islam in Indonesia can be found in the cultural values of non-Islamic religions that are maintained and practiced by Islamic entities such as practices in changing the power of kings and sultans.

In examining the system of appointment and succession (dismissal) of the king or sultan can not be separated from the problems of social and political institutions that present in power such as descent, belief, palace, and others. The traditional form presence of power with some concepts that exist in the power itself, according to the political culture adopted and determine

Copyright ( $\odot$ 2019. Owned by Author(s), published by Society. This is an open access article under CC-BY-NC-SA license. 
a process of succession of kings or sultans occurred at that time. The fusion point is to meet the two great Hindu, Buddhist, and Malay traditions in the process of creating traditional kings and sultan.

\section{Literature Review}

Horikoshi \& Wahid (1986: 76-78) stated that the nature of leadership can be built through a social process, specifically the interaction of models and figures that occur between religious leaders influencing followers, then the follower responds to the qualities they want. This charismatic phenomenon only occurs in a social interaction initiated by the appearance of a character who has inherent, learned and disciplined abilities.

Also, Syamsudin (2001: 56-58), believed that the relationship between Islam and Leadership is a classic discourse that continues to develop. In the mid-20th century Islamic countries experienced difficulties in developing a possible synthesis between Islam and Leadership, the fact explained that indeed in many Islamic countries have not been able to show a harmonious relationship between Islam and modern leadership. In his writings, Syamsudin, also sharply elaborated various paradigms of Islamic leadership and political thought in Indonesia.

Another researcher, Al-Attas (1999: 77-79), revealed that the arrival of Islam caused a rational and intellectual awakening of religious style in the Nusantara that had never been experienced before. Apart from that Islam also encourages major changes in the soul of the Malay people and their culture. Islam fosters scientific and intellectual activities and frees them from the shackles of mythology that dominated their souls before. The presence of Islam opened a new page and caused a very fundamental process of social, economic and political change. Furthermore, in society, there is a process of forming Islam into the face of power institutions around the kingdom which had previously been influenced by Malay and local civilizations. From Pasai and Aceh, Islam then spread to other areas in the Nusantara. Islamic empires also appeared on other islands since the 16th century AD after local authorities embraced Islam and their kingdoms were involved in regional trade activities.

Ambary (1998: 33-35) found that the Java kingdoms such as Demak, Banten, Pajang, Mataram, Cirebon, and Madura emerged in the 16th and 17th centuries AD; in Maluku: The Kingdoms of Ternate and Tidore in the 16th century; and then in Sulawesi: Buton, Selayar and Gowa, also in Nusa Tenggara: Bima and Lombok, in Kalimantan: Banjarmasin, and Pontianak, and others in the 17th and 18th centuries. Malay itself, other centers of Islamic power and civilization also emerged following the decline of Aceh Darussalam from the early 18th century AD, for example, Palembang, Johor, Riau, Banjarmasin, Minangkabau, and others.

Abdullah (2002: 7-8) stated that another important factor that caused Islam to develop rapidly was the settlements of civilization circle centers at the right three points, they are the Palace, Islamic Boarding School and Market (Abdullah, 1988, in Fadil, 1991). The palace as a center of power plays a role in politics and the structuring of social life. under the support of the ulama who were directly involved in the government bureaucracy where Islamic law was formulated and implemented.

Furthermore, the book of history is a basis of legitimacy for Muslim rulers. The pesantren (Islamic Boarding School) played a role in the field of education and was the second cultural center after the palace. The dismissal process of the Sultan in Palembang has only been found to be referenced in one of the ancient manuscripts "The Tale of Palembang" (Hikayat Palembang) (UBL Text 7) which today is in the Leiden Museum, the Netherlands.

Leur (1955: 97-99) in the dissertation studied Hinduism, Islam, and the west influences the history of Southeast Asia, in this case, Indonesia. According to Leur, the spread and 
development of Islam are directly related to international shipping, since Islamic traders are also preachers. However, the acceptance of Islam does not occur both by coercion from outside and the appeal of a higher cultural system enters the local power system.

Based on the previous findings and studies above, the influence of Islam, Malay and local traditions have shaped the conversion process in the succession of kings and sultans in Nusantara including the Sultanate of Palembang. It is just a necessary sorting out in terms of institutionalization of power related to the succession, awarding titles associated with religion, for example, the used of the kings of Mataram by using titles Panembahan, Susuhunan or Sultan and the title of Sayidin Panatagama as shown in the series of titles used by Susuhunan, the kings of Surakarta, as well as the sultan, the kings of Yogyakarta, showed that these kings were considered religious leaders. The title Khalifatullah as used in the Sultans of Yogyakarta also shows the religious element in the position of king.

Thus, various theoretical constructions and the previous studies on the system of appointment and Succession (Dismissal) of the King or Sultan in Nusantara constantly involve cultural issues and the institutionalization of power which is influenced by Islam, Malay and local traditions. Therefore sociological analysis through patron-client and charismatic theory is used to explore the political system, which includes charismatic or traditional authority, patrimonialism, feudalism, traditional bureaucracy, and so on since the realm of Kings and Sultans is included in classical historical studies characterized by symbolic values in a society that has a genealogic-heretically-based (hereditary) and charismatic type of leadership.

For this reason, this study seeks to explore further other matters that have not been the focus of previous researchers in the legitimacy of leaders or kings, which lies in the values of tradition, which shape the leader charismatic either from descendants or existing symbols.

\section{Research Methodology}

This study used a qualitative method and literature review. This study seeks to reveal the dynamics of social, political, cultural change in the process of Islamization and institutional processes as well as the sociocultural process of Islam and Malay in the Sultanate of Palembang Darussalam. To sharpen this study, certain themes from the history of Sultanate of Palembang Darussalam was taken, for example, the formation process of the Sultanate of Palembang and the use of the word "Kesultanan (sultanate)", Political Succession Traditions of the Sultanate of Palembang, The Ulama (Islamic elders) of the Sultanate, the pattern of Arab Muslim formation and Malay Muslim entities, emergence of Arab adaptation strategies and indigenous, and the formation of political institutions from the kingdom to the sultanate.

Sociological and historical understanding related to all historical and historiographical experiences becomes very important. Since the expression of ideas, ideas, thoughts, beliefs, organizational systems, social systems and cultural systems that move the other historical experiences, especially the process of Islamization that takes place simultaneously with the expansion of trade activities that cannot be separated from the emergence of new economic centers in the local kingdom that has strong Islamic characteristics. The existence of religious and economic social networks is very important for the continuation of the role and function of Muslims in trading activities and relations with the role of the local kingdom.

This study had two sources of data, they were: (1) Literature review and documentation as primary data; (2) Field sources as secondary data were used as complementary information sources. The data sources of literature review and documentary were sought by observation techniques and documentary studies, both books, and other literacy methods; Islamization, Arabic, and indigenous people, the history of Palembang, History of Palembang Sultanate and

Copyright ( 2019. Owned by Author(s), published by Society. This is an open access article under CC-BY-NC-SA license.

https://doi.org/10.33019/society.v7i2.108

216 
the formation of the Sultan's successional pattern in the Sultanate of Palembang Darussalam such as (1) Rahim (1998), "Sistem otoritas dan administrasi Islam di Palembeng: studi tentang pejabat agama masa kesultanan dan kolonial di Palembang"; (2) Resink (1987), "Raja dan kerajaan yang merdeka di Indonesia, 1850-1910"; (3) Ricklefs (1990), "Sejarah Indonesia Modern"; (4) Saleh (1999), "Mitos dan Legenda dalam Konsep Kerajaan dan Kenegaraan Melayu Tradisional" in Hashim \& Perret (1999); (5) Wolders (1975), "Het Sultanaat Palembang 1811-1825"; (6) Azra (2002), "Islam Nusantara: Jaringan global dan lokal"; (7) Berg (1989); "Hadramaut dan koloni Arab di Nusantara", Translation by Rahayu Hidayat; (8) Hanafiah (1988), "Kuto gawang: Pergolakan dan permainan politik dalam kelahiran kesultanan Palembang Darussalam"; (9) Sevenhoven (1971), "Lukisan Tentang Ibukota Palembang", Translation by Sugarda Purbakawatja. (10) Zuhdi et al., (1996), "Kerajaan tradisional Sulawesi Tenggara: Kesultanan Buton"; (11) Ali (1986), "Refleksi paham 'kekuasaan Jawa' dalam Indonesia modern"; (12) Hasymy (1993), "Sejarah masuk dan berkembangnya Islam di Indonesia"; (13) Leonard (1988), "Persekutuan Aneh Pemukim Cina, Wanita Peranakan dan Belanda di Batavia VOC", (Translated); (14) Budi (2005), "A Study on the History and Development of the Javanese Mosque: Part 2: The Historical Setting and Role of the Javanese Mosque under the Sultanates".

The secondary data were generated by interviews with some informants. This technique was to better understand the cohesive interpretations of various historical data found. The result is a chronological description, a reconstruction and a strong conclusion to the study subjects.

Interpretation analysis was to understand the various circumstances that are in social relations, conflicts and dynamics of power formation such as status, roles, values, norms, knowledge, ideas, symbols, which describe events. This analysis is a method in cultural science to result in scientific knowledge of objectivity. Hence, this analysis was used to address neglected dimensions in sociological analysis, namely the analysis of social, cultural, and material aspects by understanding the meaning related to historical or social situations that view the social-cultural environment as a phenomenon of human creation. This study focused on the shared-meaning in a social process which was expected to explain the significance of existing conditions and relationships and implicitly create conflict and the deepest insights were obtained about the actions that occurred in social relations.

The data was validated using triangulation techniques. According to Sutopo (2002: 7-8) triangulation is the most commonly used for increasing validity in qualitative research. Patton (in Sutopo, 2002: 78) stated four kinds of triangulation techniques, they are (1) data triangulation, that is, researchers in collecting data must use a variety of different data sources, (2) methodological triangulation is a way for researchers to test the validity of data by collecting similar data but by using different data collection techniques or methods, (3) investigator triangulation, which is the results of research both data or conclusions about a particular section or the whole can be tested for validity from several researchers, and (4) theoretical triangulation, namely in testing the validity of the data using the perspective of more than one theory in discussing the problems examined, so that it can be analyzed and drawn more complete and comprehensive conclusions. This study used the theoretical triangulation technique to validate the data. The theoretical triangulation technique tested the validity of the data using more than one perspective in discussing the problems being studied so that it can be analyzed and drawn more complete and comprehensive conclusions.

In the context of this study, the relevant data related to Malay political culture were collected and grouped them based on the method used, inventorying conclusions related to the existing literature, which were finally tested with relevant theories to draw complete conclusions.

Copyright ( 2019. Owned by Author(s), published by Society. This is an open access article under CC-BY-NC-SA license.

https://doi.org/10.33019/society.v7i2.108

217 


\section{Results and Discussion}

\section{A. The Succession of the Kings and Sultans of The Sultanate of Palembang Darussalam}

In Indonesia, the system of succession for the kings had been standardized in a particular way in the form of their respective traditions and customs. However, history also records the frequent conflicts between the royal elite during the succession process. It happened when the ruling king before did not appoint a successor or had not appointed the crown prince. The intrigue among princes often sparked the process which often leads to death among one of them. It also happened to the kingdom or Sultanate of Palembang Darussalam. To explore the process of replacing kings and sultans in Palembang, it can be seen in the book "Het Sultanaat Palembang" compiled by Woelders based on several manuscripts in Leiden, Netherlands. The text is given UBL Text Codes 4 - 7, TR-1, TR-3 and Text KI-4 (Woelders, 1975).

The list of the kings and sultans who ruled in Palembang is also included in table 1 listed by Husni Rahim concerning various sources (Rahim, 1998). However, there is a difference between lists. Husni Rahim listed the table begins with Aria Dilah, while the others begin with Ki Gede Ing Suro. On the other hand, based on the old manuscripts compiled by Woelders there also appears to be differences, especially in the reign of kings and sultans when ruling. Nonetheless, the texts all include the name of Ki Gede Ing Suro as the first ruler in Palembang. Although as a forerunner to genealogy is not always the same. UBL Text 6 (The Book of Toeroenan Radja-radja in Palembang), for instance, stated that the genealogy of the kings of Palembang starts from Sayyidina Husin.

The differences between the length of reign- ruling kings and sultans can be attributed to the period of writing these texts which all originated after the abolition of the monarchy. UBL texts 4-6 written in 1851; while the UBL-7 text was written between 1863-1880 (Woelders, 1975). The process of reign-succession in Palembang began with the reign of Ki Gede Ing Suro until the abolition of the monarchy by the Dutch Colonial in 1823. In the book "Het Sultanaat Palembang" and the oral traditions of people in Palembang, the first ruling - king in Palembang was Ki Gede Ing Suro. According to De Graaf \& Pigeaud (2001), Ki Gede Ing Suro Tua was considered as the first king and ruled from 1547 to 1552. Ki Gede Ing Suro Tua was one of the fugitives from Jipang who later took office in Palembang in 1541.

This year's figures were obtained by De Graaf \& Pigeaud based on de Kock's notes (De Graaf \& Pigeaud, 2001: 337). However, Sturler (1943) stated that Ki Gede Ing Suro Tua arrived in Palembang in 1549. This year's figure was approved by Graff \& Pigeaud because in 1541 Sultan Trenggono was reign in Demak. Apart from the year difference of Ki Gede Ing Suro's arrival, it is clear that this figure was never buried in Palembang since the King died while on a voyage back to Java. According to Husni Rahim, the length of Ki Gede Ing Suro reign was 21 years. Husni Rahim also mentioned that before Ki Gede Ing Suro was in the reign, Prince Sido Ing Lautan, whose reign lasted for 5 years. Meanwhile, according to the text TR-1, his reign is 22 years.

From the length of reign, it can be concluded that at that time Palembang's condition was stable. Thus, it is possible if before returning to Java, the King mandated to the brother, Ki Gede Ing Suro Muda to rule in Palembang which then ruled Palembang from 1572-1589 or for 17 years. The number of years mentioned by Husni Rahim turns out to be different from what is contained in the text TR-1, which mentions his reign was only one year, which began in 968 Hijri. Ki Gede Ing Suro Muda is the possibility of building a funeral complex in Gedingsuro. This figure is also known as Ki Gede Ing Suro Ilir or Kiai Mas Anom Adipati Ing Suro. If Ki Gede Ing Suro Ilir was only replaced in 977 Hijri, then he should have been in reign for around

Copyright (C) 2019. Owned by Author(s), published by Society. This is an open access article under CC-BY-NC-SA license. 
9 years, not one year. The difference of reign-length of Kemas Depati between Husni Rahim and TR-1 is 7 years.

The length of reign around 9-17 years is not to be short, so Ki Gede Ing Suro Ilir then handed over the rule to the son, Prince Kemas Dipati (1589-1594), so that the duration of his reign was only five years. This year's figures are also experiencing differences with those listed in the text TR-1 because it mentions the year of 977 Hijri as the beginning of his reign and was only replaced in 989 Hijri or ruling for 12 years. Apart from the difference in reign, it was clear that in 1595 the reign replaced to his brother, Pangeran Madi Angsoka (son of Ki Gede Ing Suro Muda) who ruled around 1594-1627 or around 34 -35 years. Although during the time of Prince Madi Angsoka there was an "infidel" war with Bantam. The length of Madi Angsoka's reign (34-35 years) shows the economic and political conditions at that time which were relatively stable and safe.

When Prince Madi Angsoka passed away, there was a power struggle between the son-inlaw (Prince Jambi) and two uncles of his wife (Prince Madi Angsoka's brothers) which the victory on the uncle's side. Even so, Prince Madi Alit (son of Ki Gede Ing Suro Muda) became the King then called Raja Depati (1629-1630). Prince Madi Alit only ruled for one year and he was killed due to a woman's case (De la Faille, 1971: 14). Prince Madi Alit was later replaced by his brother Pangeran Seding Puro or also called Pangeran Made Sokan, known as Raden Aria who was the son of Kiai Mas Adipati and ruled around 1629-1636. Raden Aria's reign of only seven years is relatively short, but given the title Prince Seding Puro (meaning death in the temple or palace), then his death is likely due to illness that has long suffered during his reign, therefore there is a possibility before Raden Aria died, he still had time to leave a will and appointing someone to succeed him as ruler in the kingdom of Palembang.

Then, Raden Aria was replaced by his brother Prince Seding Kenayan who ruled around 1636-1652 whose wife was Queen Sinuhun who was very well known in Palembang society (Ibid., p. 21). During the reign, there had been tensions with the Dutch in Batavia regarding the breach of contract he had committed on October 20, 1642, in favor of the Dutch. Pangeran Sedo Ing Kenayan did not fulfill the contents of the contract and raised the price of pepper in 1647, so the Dutch did not benefit from his monopoly (Rahim, 1998: 73). Although there was a "tension" with the Dutch, it seemed that the security and political conditions at that time did not have much influence and were relatively stable, so that it could rule for 16 years. It was during this reign that the "Simbur Cahaya" Law was born, which the Palembang people believed was the work of queen Sinuhun (wife of Prince Sido Ing Kenayan). The stability of Seding Kenayan's reign was also supported by the fact that he was replaced after he passed away.

After Prince Seding Kenayan passed away, he was succeeded by queen Sinuhun's nephew, Prince Seding Pesariyan (1652-1653) who was later replaced by his son Prince Seding Rajak (1653-1660). From the nickname, Prince Seding Pesariyan (meaning Prince who passed away in Pesariyan or bed), then the short period of the reign was allegedly caused by this king who suffered sudden death. Prince Sedo Ing Kenayan`s bravery against the Dutch was also followed by his successor, Prince Seding Rajak who in 1657 captured two Dutch ships in the Musi River (Ibid., p. 74). Because of that, the Dutch finally attacked and burned Kuto Gawang's palace in 1659, so Prince Seding Rajak moved to Inderalaya and until the death. Prince Seding Rajak was buried in the village of Sakatiga, Ogan Ilir Regency. His position was replaced by Raden Tumenggung or Ki Mas Endi Ario Kesumo who was known as Sultan Abdurrahman or Sultan Abdul Hamal/Jamal and another name is as Susuhunan Cinde Walang.

At this time Palembang also broke away from Mataram and claimed to stand alone. Ki Mas Endi used the complete sultan's title to become Sultan Abdurrahman (Khalifatul Mukminin

Copyright ( $\odot$ 2019. Owned by Author(s), published by Society. This is an open access article under CC-BY-NC-SA license. 
Sayidul Imam). As Palembang's first sultan he had established a new palace at Beringinjanggut and the Cinde Walang funeral complex. This appointment was accompanied by the signing of the treaty agreement between Palembang and the Dutch in 1662. One of the contents of the agreement was that the Dutch were allowed to re-establish a lodge and warehouse in a strategic place and near the river. The fortress is known as the Aur River fortress which is located in the opposite of the Beringinjanggut Palace (Ibid.).

After Sultan Abdurrahman, the Sultanate of Palembang Darussalam was ruled by Sultan Muhammad Mansyur Jayo Ing Lago in 1706 -1714. In 1709, the Sultan crowned the eldest son, Raden Abubakar as the crown prince with the title Prince Ratu Purboyo. However, this crown prince did not become a king because of his death. Therefore, his younger brother, Raden Uju, as his successor and was crowned the crown prince with the title Prince Ratu. Raden Uju was later crowned as the third sultan in Palembang with the title Sultan Agung Komaruddin Sri Teruno who ruled between 1714 and 1724 (10 years).

This replacement process seems could not be accepted by other palace elites, which was marked by a dispute between Prince Mangkubumi Muhammad Ali and his younger brother Raden Lambu Pangeran Mangkubumi Jayowikramo about who had the right to become a sultan. At the request of Sultan Komaruddin, the Dutch sent an expedition to Palembang under the leadership of Willem Daams. This expedition succeeded in driving out prince Mangkubumi and strengthening Raden Lambu's position as a candidate for a successor to the sultan.

Two years after the signing of the contract, Raden Lambu Pangeran Mangkubumi Jayowikramo was appointed sultan with the title Sultan Mahmud Badaruddin Jayowikramo or Sultan Mahmud Badaruddin I. His reign lasted from 1724 to 1758. On September 10, 1755, the contract renewal for the previous contract (June 2, 1722) signed by Paravicini and Sultan Mahmud Badaruddin Jayowikramo. With the occurrence of this agreement, it has an impact on political stability during his reign so that it can reach 34 years. This was marked by the construction of the Kuto Batu palace (Kuto Luto Palace).

In 1758, the reign was transferred to his eldest son, Prince Adi Kesumo, after becoming sultan with the title Sultan Ahmad Najamuddin Adi Kesumo who was in reign from 1758-1776. Like his predecessor, even at this time, a contract renewal with the Dutch was signed on June 15, 1763. Sultan Ahmad Najamuddin Adi Kesumo was later replaced by his eldest son with the title Sultan Muhammad Bahauddin (1776-1803). During his reign, his eldest son, Raden Hasan was crowned as the crown prince, heir to the throne of the Sultanate, was titled Raden Hasan Pangeran Ratu. Sultan Muhammad Bahauddin built the Great Kuto which was equipped with parks and houses and then occupied it on Monday the 23rd of Sya'ban in 1211 Hijri (February 21, 1797 AD). Prince Ratu then occupied Kuto Lamo, which was built by Sultan Mahmud Badaruddin Jayo Wikramo.

According to a book compiled by Badan Pengembangan Pariwisata Daerah Kotamadya Palembang (the Regional Tourism Development Agency of Palembang Municipality) in 1984, entitled "Sultan Mahmud Badaruddin II" stated that according to applicable regulations the eldest son of a king is the crown prince and is the rightful heir. Even so, his appointment as a sultan still had to get approval from the results of deliberations consisting of court officials and religious scholars. Based on this deliberation in April 1804, Raden Hasan Pangeran Ratu had crowned the sultan with the title Sultan Mahmud Badaruddin II; while Sultan Muhammad Bahauddin has the title Susuhunan Muhammad Bahauddin. From ancient manuscripts, it is known that the sultan is located in the Old Kraton or Kuto Batu Palace, while Susuhunan is located at Kuta Anyar Fortress or Kuto Besar Fortress.

Copyright (C 2019. Owned by Author(s), published by Society. This is an open access article under CC-BY-NC-SA license. 
At the same time Raden Hasan Pangeran Ratu's sister, Raden Husin Pangeran Adi Penggalo was appointed as a Prince, Duke of the State as the daily execution of the government. During the reign of Sultan Mahmud Badaruddin II, there was a burning of Dutch fortress on the River Aur on September 14, 1811, known as the Aur River Event. This event marked Palembang's independence which had long been under Dutch rule. But not long after that, namely, on March 20, 1812, Governor-General Raffles sent a military expedition to Palembang, then attacked Palembang and succeeded in occupying it, so Sultan Mahmud Badaruddin II resigned to Muara Rawas after handing over the leadership of the government to his younger brother Prince Adipati Penggalo Husin Diauddin and ordered to remain in Palembang (Anonymous, 1984: 29-30). Raden Muhammad Husin Diauddin was appointed sultan by the British with the title Sultan Ahmad Najamuddin II (1912-1813) (Rahim, 1998: 80). The appointment was intended to divide them.

The Dutch reappointed Sultan Mahmud Badaruddin II as a sultan from July 13 to August 14, 1813 (about one month). On August 14, 1813, to June 23, 1818, the British deposed Sultan Mahmud Badaruddin II and appointed Sultan Ahmad Najamuddin II as ruler of Palembang. On the other hand, the two brothers had also ruled together, namely between June 23 and October 30, 1818. Sultan Ahmad Najamuddin II ruled in Kuto Luto Palace as the Sultan Mudo; while Sultan Mahmud Badaruddin II came to rule in Benteng Kuto Besar as Sultan Tuo.

There was a period of his reign this time, in 1819, Sultan Mahmud Badaruddin II named his son Pangeran Ratu as a sultan with the title Sultan Ahmad Najamuddin Pangeran Ratu (Sultan Ahmad Najamuddin III). At the same time, Sultan Mahmud Badaruddin II was entitled Susuhunan Mahmud Badaruddin. On 1 July 1821, the palace was occupied by the Dutch and on 3 July 1821 Susuhunan Mahmud Badaruddin and Sultan Ahmad Najamuddin Pangeran Ratu were arrested and exiled to Ternate. On 26 November 1852 Susuhunan Mahmud Badaruddin died, while Sultan Ahmad Najamuddin Pangeran Ratu died in 1860.

To fill the power vacuum in Palembang, the Dutch called back Sultan Ahmad Najamuddin II and his son from his exile in Cianjur. From July 16, 1821, to September 19, 1825, Sultan Ahmad Najamuddin Prabu Anom, son of Sultan Ahmad Najamuddin II was appointed Sultan of Palembang by the Dutch, while Sultan Ahmad Najamuddin II had the title Susuhunan Husin Diauddin. On November 22, 1824, Sultan Ahmad Najamuddin Prabu Anom with the knowledge of his father rebelled against the Dutch, which led to the arrest of Susuhunan Husin Diauddin and exiled to Batavia and died on February 22, 1825. While Sultan Ahmad Najamuddin Prabu Anom was captured by the Dutch from October 15 and October 19 in 1825 was exiled to Banda and then to Manado and died there in 1844 (Ibid., p. 287-289). The Sultanate of Palembang has ended marked by the abolition of the Sultanate and the transfer of reign over Palembang and the people of Palembang to the Dutch.

According to Rahim (1998: 81-82), the abolition of the Sultanate took place around August 18,1823 , the date of the signing of the agreement on the transfer of reign and the abolition of the Sultanate of Palembang (Ibid.) In the Nusantara, generally, political entities were called kingdom. Milner (1982) called it "the condition of having a king". This Islamic political entity is a continuation of political entities in pre-Islamic times, where the king has a very important position and is often seen as an enlightened bodhisattva.

The arrival of Islam does not seem to change the essence of the political entity, especially regarding kings and kingdoms, because the conception of the concept around this issue is not considered to be contrary to Islamic teachings, it has even gained legitimacy from the Ulamas. At the end of the Palembang Sultanate was the abolition of the Sultanate and the transfer of government over the Land and the people of Palembang to the Dutch. The transfer of reign can

Copyright (C 2019. Owned by Author(s), published by Society. This is an open access article under CC-BY-NC-SA license.

https://doi.org/10.33019/society.v7i2.108

221 
be read in the notice of the transfer of reign of the Sultanate of Palembang to the Dutch as follows:

That this is the legal newsletter. That Sri Paduka Ratu Ahmad Najamuddin the sultan of Palembang gave safety to anyone who saw, heard or read this letter. That like an agreement made from all the good pleasure of both parties, namely between the Governor of the Dutch and Sri Paduka Tuan Sultan to improve the fate of us, the people, thus from now on all the orders and governance of the land of Palembang and the people of all people were handed over to the Dutch Governor. As for the Sri Paduka Sultan will be in a position to give an opinion to weigh the penalty for error and ... (unreadable) his world. And from that religious matter will be decided by the prince of penghulu according to the law in the Quran; and if you do not accept the decision of the penghulu, may ... (unreadable) talk to us. That all governments as well as ... (unreadable) or results are held by the Governor. That we, Sri Paduka Tuan Sultan will use our glory and respect ... (unreadable) always do that with perseverance, privileges to facilitate the people in carrying out all the regulations of the Dutch government. That we pledge solemnly to carry out such provisions is to command all priayi and mantras and the people of the country, uphold the orders that will be given by him, the Governor; That the Governor of the Dutch has been established in our and priayi lives and mantras so we can no longer collect results and... (unreadable) as before; That everyone who holds the charter of surrender to the Governor of the Dutch, that is all the charter that were handed over by us or by the previous Sultan of Palembang. Then the charter should be handed over as soon as possible and to each of the head of the village and the heads of sub-villages and to immediately give the presence of the Governor. To hear his precepts from the matters of the charter and of becoming ... (unreadable) later on. To be conveyed to all people in all corners of the country, this letter must be read, pasted and copied so that it can be known by everyone. Sri Paduka Tuan from the Sultan of Palembang on Monday the eleventh day of the month of Dhul-Hijjah, in the year of one thousand two hundred thirty-eight. (Rahim, 1998: 81-82).

From this explanation and historical data regarding the kings and sultans who had ruled Palembang Darussalam, it can be seen that there are no standard rules or laws regarding the process of replacing or inheriting the throne during the Kingdom of Palembang. These conditions prone to conflict, because each character feels entitled to the royal throne. Therefore, it is not surprising to see that there is the inheritance of lineage that younger brothers or even younger brothers from the empress can occupy the throne of the kingdom or sultanate. This can be seen from the succession process from the reign of Ki Gede Ing Suro Tua to Pangeran Sedo Ing Kenayan, from 1552-1652. Over a period of 100 years, the change of reign in Palembang has occurred 10 times. Only four of the ten kings had ruled for more than ten years, including Ki Gede Ing Sura (26 years); Ki Gede Ing Sura Muda (17 years); Prince Madi Ing Angsoka (34 years) and Prince Sedo Ing Kenayan (11 years). The other kings is in reign for less than ten years.

Two kings were in reign for only about one year, namely Pangeran Madi Alit and Pangeran Sedo Ing Kenayan. Besides, Kiai Mas Adipati only ruled for 5 years; Pangeran Sido Ing Puro ruled for 9 years; and Prince Sedo Ing Rajek ruled for 7 years. The internal conflict of the elite of Palembang Sultanate was also triggered by competition between other paternal relatives to fight for reign. The wife of the kings, who are more than one, is one of the triggers for internal conflicts among the Palembang royal family (Purwanti, 2004: 34). 
This situation has been resolved since Kiai Mas Hindi or Pangeran Ario Kesumo Abdurrohim plotted to establish the Sultanate of Palembang and to be separated from Mataram. This is evident from the appointment of the crown prince, who was the sultan's first child with the empress. The crown prince was given the title Pangeran Ratu. Although written rules regarding the right of inheritance of the throne before Sultan Mahmud Badaruddin II had no known textual source, from the old Palembang texts, it was known that before the ruling sultan died or abdicated, he had appointed a crown prince with the title Pangeran Ratu. The coronation as the crown prince, often even continued with the coronation concerned as a new sultan complete with his title.

Meanwhile, the previous sultan still ruled and later took the title "Susuhunan". Even though a new sultan has been appointed, it does not mean that the previous sultan, who had the title "susuhunan" was immediately "lengser keprabon" or abdicated, and no longer holds the reins of government. Based on textual sources, it turns out that the opposite happened, Susuhunan remained in full reign alongside the sultan who had just been crowned.

This was also strengthened by the stamp of the Palembang Sultanate, the legacy of Sultan Mahmud Badaruddin II, which had 1819 AD $(1234 \mathrm{H})$. At the time of issuing the stamp, Sultan Mahmud Badaruddin II had laid down his throne and crowned his son, Pangeran Ratu as a sultan with the title of Sultan Najamuddin Pangeran Ratu. After crowning his son, Sultan Mahmud Badaruddin II then took the title Susuhunan, as stated on the stamp (Purwanti, 2002: 119).

Here it appears that there was a process of "learning" for the new sultan in the matter of leadership or the government, before the Susuhunan released himself fully as the ruler of the sultanate (regeneration). Then, from textual sources also obtained information that since the use of Benteng Kuto Besak, the Crown Prince lived in the Benteng Kuto Lama, while susuhunan lived in Benteng Kuto. The difference in location and the continued reign of the susuhunan were actually utilized by the Dutch and British to complicate the process of succession of reign in the Sultanate's palace, by divide and conquer between the two sultans. This effort was so successful, that in the eleven years, the British and the Dutch succeeded in raising and lowering the siblings six times until the abolition of the Sultanate of Palembang.

The process of succession the Sultan of Palembang Darussalam has only been found to be referenced in one of the ancient manuscripts "The Tale of Palembang" (UBL Text 7) which is now in the Leiden Museum, the Netherlands, stated that the process of appointing a king as follows:

As for the story of all the kings who ruled over the throne of the Palembang kingdom, there were too many rules about the succession of the king who reign in Palembang. Sometimes the rules are indeed replaced by his son who becomes king and sometimes because of war and sometimes because of a will. When the king was still alive, the king would testify to all his ministers and dignitaries with an oath: "If I die, that person (a certain person) will replace me; I don't like my son to become a King". This is what all the ministers and all the people in Palembang do as the will does. Then sometimes with the cause of war with the white people (Dutch). And if the king loses to that war, the King of Palembang retires upstream, no longer wants to go to downstream of Palembang, and the king will order his brother as a substitute to become a king on the throne of Palembang to hold off white speech. (Woelders, 1975: 74)

Based on the manuscript written between 1863-1880 (Ibid., p. 49), the process of succession the kings in the kingdom of Palembang Darussalam can vary, but one thing that must be noted

Copyright (C 2019. Owned by Author(s), published by Society. This is an open access article under CC-BY-NC-SA license.

https://doi.org/10.33019/society.v7i2.108

223 
is the sentence "Sometimes the rules are indeed replaced by his son who becomes king...". This sentence confirms the existence of a kind of standard rules about the process of succession of the king who is considered legitimate and has strong legitimacy, namely that his successor is the king's son who ruled before. Although the sentence does not mention which king's son has the right to replace the previous King. But from the text it can also be seen that, before the reigning king abdicated or died, the king appointed the crown prince and gave the title Pangeran Ratu. The title of the crown prince during the reign of Sultan Muhammad Husin Diauddin was titled Prabu Anom because the title Pangeran Ratu had been used by the crown prince who was appointed by Sultan Mahmud Badaruddin II. On the other hand, from the fragments of the sentence in the manuscript, it can be ascertained that the previous reigning king had the highest authority to determine his successor, even though through a message or letter in the form of a will.

The results of the traditional deliberations held on February 24, 2003, at the Auditorium of Raden Fatah State Islamic Institute Palembang of Palembang (now State Islamic University), which wanted no confusion in determining the requirements of Palembang Darussalam's prosperity for historical purposes. The traditional deliberations then compiled a draft containing guidelines or conditions to become sultan. The requirements as a sultan of Palembang are as follows (Siregar, 2004: 73-74):

1) Muslim, including the family.

2) From the Sultanate of Palembang Darussalam descendant (preferably from zuriat of Sultan Mahmud Badaruddin II).

3) Having evidence of the Trust (in the form of relics from the Palembang Darussalam sultans).

4) Known by the people of Palembang and other sultanates.

5) It can encourage the spirit of unity and the unity of people in Palembang Darussalam.

6) Caring about the legacy of the Palembang Darussalam Sultanate.

7) Not directly or indirectly involved in the destruction or sale of assets of the Palembang Darussalam Sultanate.

8) Dare to sacrifice for the progress and pride of zuriat.

9) Residing in Palembang, getting to know Palembang.

10) High educated at least high school.

11) Experienced in an organization.

Djohan Hanafiah, one of the Palembang`s historical and cultural observers, gave different requirements. He argued that the criteria for becoming a sultan were genealogical, geographical, royal symbols and community recognition (Siregar, 2004: 69). Referring to the opinion expressed by Mustofa Al-Azhari, a Palembang cleric, Rahmawati Siregar said that to determine someoness right to become a sultan, not only in terms of genealogical factors, territory, power and community recognition but also must be seen in terms of message ownership special messages from the ancestors. This means that the sultan is a chosen person from the ancestors, and also supported by informal legitimacy obtained by someone because of their capacity in a field considered qualified by the community, for example, "clerics" for the ulamas. This informal legitimacy can be seen from the wide acceptance of the people concerned in a wide and unconditional way.

Based on the explanation of the concept of the State and the position of the king above concerning the process of succession, it can be explained that in outline three important elements must be possessed by a sultan so that his reign has legitimacy and credibility, namely 
genealogical, geographical and symbols or signs the greatness of the kingdom (Regalia) which is usually inherited from its predecessors. Without these three elements, the legitimacy of a king's position becomes weak and vulnerable to rebellion. Indeed, in one of the requirements for the appointment is heirlooms' ownership, for example:

$>$ The cane of Sultan Mahmud Badaruddin II which it was used for war;

$>$ The stamp of The Sultanate of Palembang Darussalam;

> Istambul (a necklace containing a small Koran) made of copper;

$>$ Clothes in the form of Sultan Mahmud Badaruddin's II robe;

$>$ Manuscripts were written by Sultan Mahmud Badaruddin II;

$>$ Manuscript of Sultanate zuriat.

According to tradition, so-called the sultanate heirlooms (regalia) are things that are owned by a kingdom from its inception (the first king/sultan), and these objects are passed down from generation to generation. More than that, the heirlooms became a symbol of the legitimacy of the crowned king and the symbol of his kingdom's sovereignty. Even these regalia objects become the most important part of the rapture ritual of a king. This heirlooms (regalia) is commonly found in kingdoms in Southeast Asia (Heine-Geldern, 1982).

\section{B. Sociological Analysis on Succession of The Sultan}

After the fall of the Srivijaya kingdom, the Palembang region experienced a vacuum of power for approximately one hundred years. The new government emerged in the sixteenth century. Ki Gede Ing Suro is considered to be the founder of the reigning kingdom of Palembang in the sixteenth century. According to Woelders (1975), Ki Gede Ing Suro held the position of King in Palembang which was then followed by Gending Ilir. Ki Gede Ing Suro ruled in the Kingdom of Palembang for 2 years. Ki Gede Ing Suro was then succeeded by his brother Gending Ilir who ruled for 1 year and so on as described above.

The title of the sultan used by the authorities indicates that the king is Muslim. At the beginning of the 16th century when the Europeans were present in the Palembang region, they tried hard to obtain trade commodities directly to obtain large economic benefits. Here is the influence of Europeans on the existence of a King, Ki Gede, or Sultan who is not only acknowledged from his culture but also his belief culture. The Europeans have succeeded in making the Muslim King add the title of Sultan, this is done to strengthen power and law against native rulers. They were awarded various signs of greatness as a symbol of power. As a result, in the Sultanate of Palembang itself, competition arose between members of the royal family and the sultan who wished to rule as well.

The succession of reign in the time of the Kingdom of Palembang generally occurs in several Hindu-Buddhist Kingdoms in Java, namely genealogy and dignity. This also applies in reading the leadership succession process in the past, when political unity was still in the form of a kingdom or sultanate, which in some regions of the Nusantara continues to this day. Especially if it is seen that the appointment of a king (sultan) is inseparable from the concept of the State (power), which of course is different from the concept of the modern state introduced by the Western Country.

Because the King or Sultan is a type of leadership that occupies a socio-historical location with different value orientations so that their reactions to their existence are also different in the form of rejection, adaptation, and assimilation. Not infrequently present political conflicts caused by sociocultural factors with certain ideological or value interests. No less important is 
the structural analysis that discusses the status and role of various elites, the relationship, and comparison of power between them, all within the hierarchical framework of a feudal system.

The power structure is a very determining social structure with a bureaucratic position that is a very central function. In this connection, it is very relevant to examine social life between social groups, especially in the context of interests, social status, ideology, and value systems. It cannot be ignored by the fact that political actions and interactions cannot run outside the framework of political culture.

Here actions, actions, and attitudes need to be institutionalized. For example, the role of a character is determined by the structure of society, or at least its role is carried out within the structural boundaries of society. Perpetrators cannot completely disengage from such ties or subjectivity.

In the theoretical framework of leadership type sociology which according to Weberian theory there are three, namely: (1) traditional authority owned by inheritance or hereditary; (2) charismatic authority, which is based on personal influence and authority; and (3) rational-legal authority possessed based on position and ability. The formal type of leader obtains power from the position or formal leader, while the informal type is the informal leader, and he has charismatic power. In the Indonesian context, the formal type in general also has traditional authority, is the aristocracy group who still have the right to inherit positions, especially those who hold civil service positions (Weber, 2009).

Borrowing the theory of Bendix (1960), power and authority, and feudal societies in Europe. Then Weber in the 19th century and early 20th century also explained the patron-client relationship through his theory, namely: (1) traditional theories, (2) charismatic, and (3) rational. In traditional relationships, a patron gets its position through a hereditary. This power gained from generation to generation was discussed by Bendix but it did not discuss the clientpatronage of rational leadership. He mentioned a charismatic ruler a little. In charismatic relationships, a patron has many clients, followed by many people because of their charisma, such as religious figures, priests, and Kiai ( Islamic elders).

The succession of reign system in the Sultanate of Palembang Darussalam is a manifestation of various values, interests, and cultures, where the concept of leadership is based on traditional authority based on cultural recognition. This type makes it easy to influence the community, so traditional leadership cannot be separated from genealogic-heretically (hereditary) and charismatic-based leadership.

However, between these two basic typologies of leadership, charismatic-based leadership is the basis of any traditional leadership in various social entities. Weber's concept of charismatics is an argumentative-comparative discussion that is the experience of religious communities in the world. In the Middle-Century in Western Europe, which began in the 13th century, until the Industrial Revolution, it turned out that the priests had authority in religion, social, politics, economics, thus forming charismatic values (Weber, 2009).

In the 19th century, the charisma of Islamic leaders in Indonesia, namely the Kiai occupied charismatic leadership. Regardless of any background that underlies the determination of conditions as a sultan is a descendant (in Islamic term known as zuriat) of the Sultanate, this tradition can be justified. However hereditary or genealogical factors become one of the determinants of the legality and sovereignty of political unity in the past. The king is seen as the center of the Cosmos and from the king emanates a power that affects both nature and society. Placement of the king as a descendant of the prophets and gods is intended to strengthen the legitimacy (legitimacy) as a king. This assumption is related to the magical beliefs of the king's revelations (it is known as pulung ratu) and the concept of the royal bloodline (trahing kusuma

Copyright (C 2019. Owned by Author(s), published by Society. This is an open access article under CC-BY-NC-SA license. https://doi.org/10.33019/society.v7i2.108

226 
rembesing madu). Among Javanese, there is the assumption that only men who have the blood of kings can be a king.

This concept is not something new, because in the concept of royal power in Java, for example (and Southeast Asia in general), the position of king is most often validated (also) by proving continuity. A blood relationship or experience similar to that of a great predecessor allows a person to be illuminated by an aura of light. Not only that but the most important thing from searching for genealogy is that it can make it a chain of continuity. In the Javanese concept of trahing kusuma rembesing madu, ascetic life, tedaking andana warih (flower derivatives, honey extracts, ascetic seeds, noble derivatives) are the characteristics of the grand and immaculate ancestors.

Therefore, tracing one's genealogy, if possible the origin of someone in power or a great subordinate king, is something that is cultivated with a lot of time-consuming and earnest sincerity. The arrival of Islam did not eliminate the habit of proving continuity through kinship (Berg, 1989: 96, vide Leirissa, 1996: 62) and this was reinforced by Arabic custom, which was usually followed by people of rank in Java, to combine the name of an ancestor with his own name. The demand for continuity is also stated in the Islamic provisions regarding Islam isnad ${ }^{1}$.

Based on the explanation above, it can be seen that the process of appointing kings or sultans who had ruled in Palembang was no different from those in other sultanates that had ever existed on this Nusantara. Although this political unity breathes Islam continues what has existed in the past, namely the Hindu-Buddhist Concept, while Islam sometimes appears in the socio and political aspects. The same thing applies to aspects of its legality. In addition to the two aspects above, namely legality and symbolization, the most important is the organizational structure "led" by a Sultan. This is because the title "sultan" can refer to someone who unites the exercise of supreme power and various magical and mystical symbols, which reveal the quality of the instruments of power (Kartodirdjo, 1969: 13).

So the emergence of two sultans in the sultanate of Palembang was an unusual phenomenon released from what was called status, powershift and legitimacy. Although both the sultan Prabu was his master, and the sultan Iskandar Badaruddin was made a sultan only as a symbol of the culture and nobility of the Sultanate. However, the sultan's position at the cultural symbol level has a strong influence especially on the native people of Palembang. Because as a symbol of culture, a sultan can play several strategic roles, namely as actors of the cultural system, social system, and personal system. A sultan has leadership abilities because he also acts as a center for socialization and at the same time evaluating the cultural values that live in his society.

Society according to Parsons is the fabric of the system in which various functions work such as norms, values, consensus and other forms of social cohesion. The operation of different

\footnotetext{
${ }^{1}$ During the sultanate of Palembang Darussalam, the last ruler was Sultan Ahmad Najamuddin Prabu Anom, son of Sultan Ahmad Najamuddin II or Susuhunan Husin Diauddin. So, according to tradition, and the norms prevailing in the Sultanate of Palembang since long ago, actually the right to be the next sultan in Palembang is the son of Sultan Ahmad Najamuddin Prabu Anom, who is the nephew of Sultan Mahmud Badaruddin II. Moreover, since losing the war with the British Empire and being captured by the Dutch, Sultan Mahmud Badaruddin II has never succeeded in regaining his power until he died in his exile in Ternate. Of course, someone who loses a war cannot determine his destiny, including in agreeing. Although while in exile he was treated like a sultan, but it was not something special, because Sunan Banguntapa (Sunan Pakubuwono VI) from Surakarta Sunanate also received the same treatment. Even in his exile in Ambon, Pakubuwono VI was built a palace with all its equipment by the Dutch (Day, 1989: 32-88).
}

Copyright (C 2019. Owned by Author(s), published by Society. This is an open access article under CC-BY-NC-SA license. https://doi.org/10.33019/society.v7i2.108 


\section{Malay Political Tradition:}

functions is called specialization, where each function is mutually sustaining or synergistic. One organ can be commanded by another organ, but the party giving the order does not have a higher position. This means that there is a reciprocal relationship between the giver of the command and the governed. All of which build a form of coordination between social systems. This is what is called by the supporters of the Sultan both Sultan Iskandar and Sultan Prabu Diraja regardless of both $h$ ave genealogical relations with Sultan Badaruddin II.

This study is Talcott Parsons's theory by using AGIL.

Figure 1

AGIL Theory

The Meeting of AGIL and the System
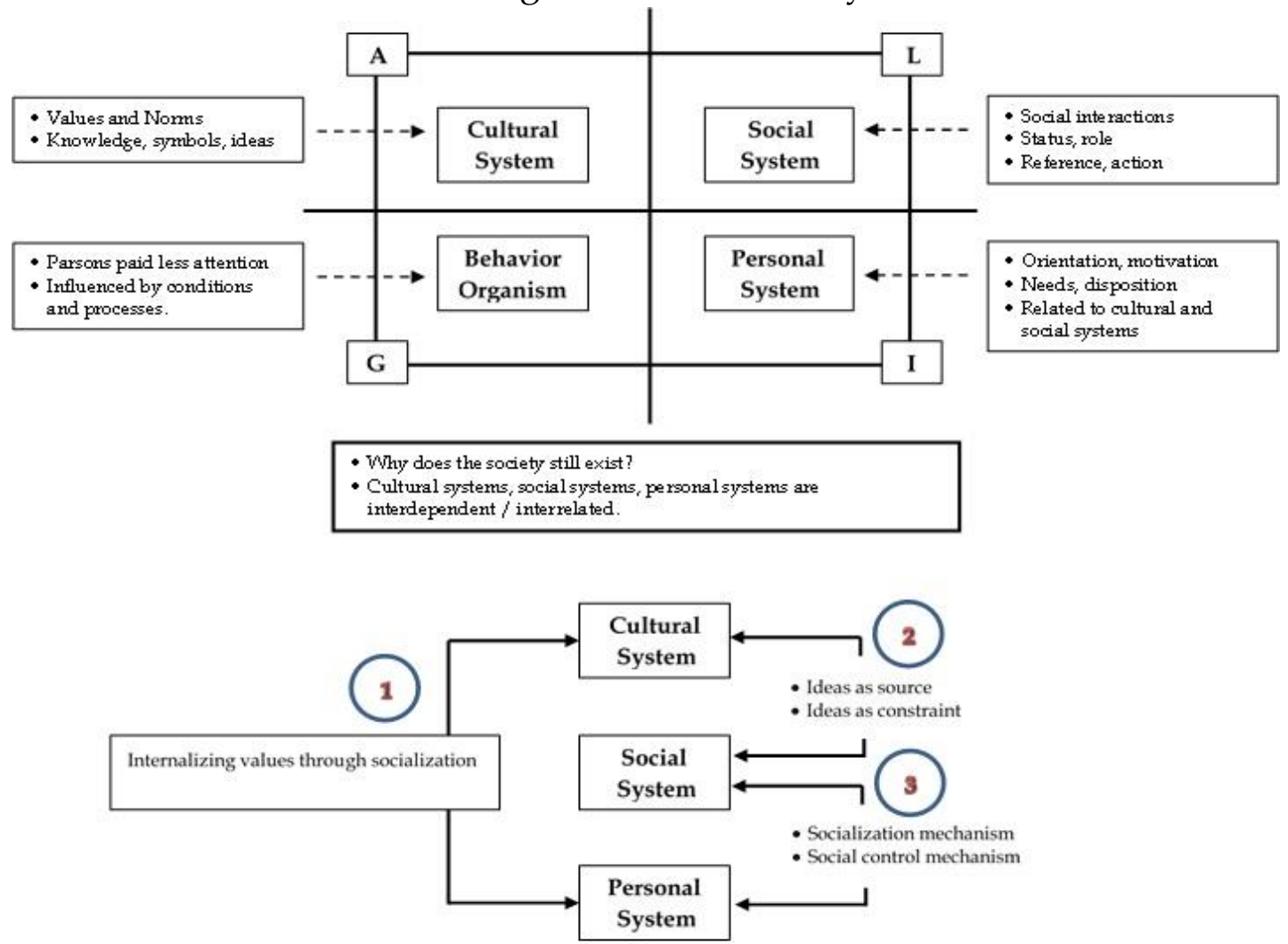

- Values, noms, knowled se, symbols, ideas are socialized continuously to form personality (orientation, motivation, needs)

- Values, noms, knowledge, symbols, ideas can be the basis of social relations, canbe corrected when it causes tension,

(re lationships that are not hamonious)

- Socialization mechanism: forcing actors to act like certain status and roles

- Control mecharism: so that social relationships match status and roles

Source: (Parsons, 1951 in Soekanto 1986)

Therefore the existence of a society that consists of social systems, cultural systems, and material systems, always requires conditions that create existence (condition of existence). According to Parsons the conditions that state the existence of the social system to stay alive and run well, there are four important functions, namely AGIL (A) Adaptation, (G) Goal Attention, (I) Integration, and (L) Latency. Adaptation: a system must cope with critical external situations, the current system adapts to its environment. Goal attainment: the system must define and achieve its main objectives. Integration (integration): a system must regulate the relationships between the parts that are components. The system must also regulate the relationships between other functions (A, G, L). Latency (system maintenance): the system must 
complement, maintain \& improve, both individual motivation and cultural patterns that create and sustain motivation ${ }^{2}$.

The meeting of AGIL (functional prerequisites) with the Social System according to Parsons as Organism behavior: a system of actions that carries out the adaptation function by adjusting and changing the external environment. Personal systems carry out the function of achieving goals by setting system goals and mobilizing available resources to achieve them. The social system overcomes the function of integration by controlling the parts that become its components. Cultural systems carry out the function of maintaining the pattern by providing actors with a set of norms and values that motivate them to act.

Functions and systems, according to Parsons, are action systems that work like behavioral organisms: action systems that carry out adaptation functions by adjusting and changing the external environment. The social system consists of some individual actors who interact with each other in a certain environment. They have the motivation to achieve the satisfaction that is defined and mediated in terms of culturally structured shared symbols. This means that in the social system there are: actors, interactions, the environment, optimization of satisfaction, culture, adequate participation from supporters. Parsons states that the key requirement for maintaining the integration of value patterns in a social system is the process of internalization and socialization. It becomes the struggle for the throne of Palembang Darussalam Sultanate, namely the authority to internalize and to socialize the logical consequences of the cultural symbol of the Sultan's position.

\section{Conclusions}

Palembang which in the Sultanate of Palembang Darussalam functioned as the center of the kingdom, in the life of the people religious ceremonies that were general and related to the kingdom, had become customary. In the chronicles, saints, and foreign news mentioned that the ceremonies and parties associated with the kingdom, such as the coronation of the king or crown prince, circumcision, the marriage of the sons and daughters of the king, the birth of the sons and daughters of the king, etc. , about the life of the king with family; ceremonies and parties with the reception of foreign emissaries, the Maulud of the Prophet, feasts, and other holidays. The ceremonies and parties are usually enlivened by a variety of crowds that involve all components of society.

One of the tasks of the sultan was to become an umaro, meaning he became a religious advisor to the government. The existence of the Palembang Sultanate is not only a cultural field but also a political element. In this study, it was found that the process of appointing kings or sultans who had ruled in Palembang was no different from those in other sultanates that had

\footnotetext{
2 Based on the Parsons concept (1951), every social system needs functional requirements. Among the requirements explained that the social system must be able to adapt to the environment and with the demands of transformation in every condition of citizens' actions (adaptation). Then, the people's actions are directed towards achieving a common goal (goal attainment). Then another requirement is that in interactions between citizens there must be at least a level of solidarity, for social structures and systems to function (integration). Talking about functions, it turns out it's not just about the role. Function relations are not always integrated (integrative) because there can be conflicting relations, especially if there are enough factions in them. In the function there is a structure, in social facts, there are structures and functions that are closely related (if no connection means no structure). Function theory is not designed with the change, so between the two is rather difficult to link. Often this theory is limited to only harmonious or equilibrium relations. See Poloma (2005). Contemporary sociological theory. Translation by the Yasogama Team. See also Hamilton (1990). Reading From Talcott Parsons. Translation by Hartono Hadikusumo. See also Ritzer \& Goodman (2005). Teori Sosiologi Modern. Translation by Alimandan.
}

Copyright (C) 2019. Owned by Author(s), published by Society. This is an open access article under CC-BY-NC-SA license. https://doi.org/10.33019/society.v7i2.108 
ever existed on this Nusantara. Although this political unity breathes Islam it continues what has existed in the past, namely the Hindu-Buddhist concept, while Islam is only as an outer garment. The same thing applies to aspects of its legality.

As a maritime and absolute sultanate, it seems that a reference that can be directed to the only absolute monarchy that still exists in Southeast Asia is the Sultanate of Brunei Darussalam. However, the origin of this empire was not from an agrarian empire which gave birth to the civilization of the palace, but from an empire at the mouth of the river and sea such as, the kingdoms in Peninsular Malaysia, Sumatra, Kalimantan, and others (Onghokham, 2003: 59).

Unlike in the sultanate of the archipelago, in the agrarian kingdom, political unity (sacral) still existed while the heirlooms still existed, and the throne was still in the holy place. In short, as long as there is a palace, the kingdom still exists and the king is still recognized by the people. Even kingdoms whose political functions had been abolished hundreds of years ago, such as the palaces in Cirebon, had their cultural and sacred functions persisted. This is different from maritime kingdoms because even though the Sultan and his palace still exist, his existence is no longer recognized by his people. Some examples can be given here is the Sultanate of Deli in North Sumatra, whose sultan was also an officer; the Bugis-Makassar sultanate in South Sulawesi.

\section{Acknowledgement}

The authors would like to thank the Research and Community Service Institute (Indonesian: Lembaga Penelitian dan Pemberdayaan kepada Masyarakat or LP2M), Raden Fatah State Islamic University of Palembang, for funding support and facilities for making this study a success through Interdisciplinary Basic Research Grant Scheme (Indonesian: Hibah Penelitian Dasar Interdisipliner (Registration ID 191160000020844, Decree Number 852, 2019)).

\section{References}

Abdullah, T. (2002). Pemikiran Islam di Nusantara dalam Perspektif Sejarah: Sebuah Sketsa. Jakarta: Prisma.

Al-Attas, S. M. N. (1999). The Concept of Education in Islam: A Framework for An Islamic Philosophy of Education. Kuala Lumpur: International Institute of Islamic Thought and Civilization.

Ambary, H. M. (1998). Menemukan Peradaban: Jejak Arkeologis dan Historis Islam Indonesia. Jakarta: Logos Wacana Ilmu.

Anonymous. (1984). Sultan Mahmud Badaruddin II. Palembang: Badan Pengembangan Pariwisata Daerah Kota Madya Palembang.

Azra, A. (2002). Islam Nusantara: Jaringan global dan lokal. Bandung: Mizan.

Bendix, R. (1960). Max Webber, An Intellectual Portrait. New York: Doubleday.

Budi, B. S. (2005). A Study on the History and Development of the Javanese Mosque: Part 2: The Historical Setting and Role of the Javanese Mosque under the Sultanates. Journal of Asian Architecture and Building Engineering, 4(1), 1-8.

Day, A. (1989). Drama pengasingan Bangun Tapa di Ambon, Puisi Kedudukan Raja di Surakarta. In Gesick, L. (1989). Pusat, Simbol dan Hirarki Kekuasaan: Esai-esai Tentang Negara-negara Klasik di Indonesia. Jakarta: Yayasan Obor Indonesia.

De Graaf, H. J., \& Pigeaud, T. H. (2001). Kerajaan Islam Pertama di Jawa. Terjemahan. Yogyakarta: Pustaka Pelajar.

De la Faille, P. D. R. (1971). Dari zaman kesultanan Palembang (Vol. 8). Jakarta: Bhratara. 
Fadil, S. (1991). Pengislaman Dunia Melayu: Transformasi Kemanusiaan dan Revolusi Kebudayaan. Dalam Dewan Budaya, 12.

Hamilton, P. (1990). Reading From Talcott Parsons. Translation by Hartono Hadikusumo. Yogyakarta: Tiara Wacana.

Hanafiah, D. (1988). Kuto gawang: Pergolakan dan permainan politik dalam kelahiran kesultanan Palembang Darussalam. Palembang: Parawisata Jasa Utama.

Hasymy, A. (1993). Sejarah masuk dan berkembangnya Islam di Indonesia. Bandung: Alam'arif. Heine-Geldern, R., (1982). Konsepsi Tentang Negara dan Kedudukan Raja Di Asia Tenggara.

Translation by D. Noer. Jakarta: Rajawali.

Horikoshi, H., \& Wahid, A. (1987). Kyai dan perubahan sosial. Jakarta: Perhimpunan Pengembangan Pesantren dan Masyarakat.

Kartodirdjo, A. S. (1969). Struktur Sosial dari Masyarakat Tradisional dan Kolonial. Yogyakarta: Gadjah Mada University Press.

Leirissa, R. Z. (1996). Halmahera Timur dan Raja Jailolo: Pergolakan sekitar Laut Seram awal abad 19. Jakarta: Balai Pustaka.

Leonard, B. (1988). Persekutuan Aneh Pemukim Cina, Wanita Peranakan dan Belanda di Batavia VOC (Translated). Jakarta: Pustazet Perkasa.

Leur, J. V. (1955). Indonesian trade and society: Essays in Asian social and economic history. Bandung: W. Van Hoeve.

Milner, A. C. (1982). Kerajaan: Malay political culture on the eve of colonial rule (No. 40). University of Arizona Press.

Onghokham. (2003). The Thugs, the Curtain Thief, and the Sugar Lord. Power, Politics and Culture in Colonial Java. Jakarta: Metaphor Publishing.

Poloma, M. M. (2005). Contemporary sociological theory. Translation by the Yasogama Team. 5th Edition. Jakarta: Rajagrafindo Persada.

Purwanti, R. (2002). Penguburan Masa Prasejarah Situs Muara Betung, Kecamatan Ulu Musi, Kabupaten Lahat, Provinsi Sumatera Selatan. Berita Penelitian Arkeologi, (7).

Purwanti, R. (2004). Perubahan Pola Permukiman Masyarakat Palembang dalam Persepektif Arkeo-Ekologi. Jurnal Tamaddun: Jurnal Kebudayaan dan Sastra Islam, 1(1).

Rahim, H. H. (1998). Sistem otoritas dan administrasi Islam di Palembeng: studi tentang pejabat agama masa kesultanan dan kolonial di Palembang. Jakarta: Logos Wacana Ilmu.

Resink, G. J. (1987). Raja dan kerajaan yang merdeka di Indonesia, 1850-1910: enam tulisan terilih. Djambatan.

Ricklefs, M. C. (1990). Sejarah Indonesia Moderen. Translation by D. Hardjowidjono. Yogyakarta: Gadjah Mada University Press.

Ritzer, G., \& Goodman, D. J. (2005). Teori sosiologi modern. Jakarta: Prenada Media, 121.

Saleh (1999). Mitos dan Legenda dalam Konsep Kerajaan dan Kenegaraan Melayu Tradisional. In Hashim, H. W. T., \& Perret, D. (1999). Di sekitar konsep negeri. Kuala Lumpur: Kementerian Kebudayaan, Kesenian, dan Pelancongan Malaysia.

Sevenhoven, J. V. (1971). Lukisan Tentang Ibukota Palembang. Jakarta: Bhratara.

Siregar, Rahmawaty. (2004). Menelusuri pewaris tahta Kesultanan Palembang Darussalam.

Skripsi. Palembang: Fakultas Adab dan Humaniora, IAIN Raden Fatah Palembang.

Soekanto, S. (1986). Talcott Parsons: Fungsionalisme Imperatif. Jakarta: Rajawali.

Sturler, W. L. (1943). Proeve eener beschrijving van het gebied van Palembang, (Zuid-Oostelijk gedeelte van Sumatra. Groningen: Oohmens.

Sutopo, H. B. (2002). Metodologi penelitian kualitatif. Surakarta: Sebelas Maret University. Syamsudin, M. D. (2001). Islam dan Politik Era Orde Baru. Jakarta: Logos Wacana Ilmu. 
Van den Berg, L. W. C. (1989). Hadramaut dan koloni Arab di Nusantara (Vol. 3). Translation by Rahayu Hidayat. Jakarta: Perpustakaan Nasional.

Weber, M. (2009). The theory of social and economic organization. Simon and Schuster.

Woelders, M. O. (1975). Het Sultanaat Palembang 1811-1825. 's-Gravenhage: Nijhoff.

Zuhdi, S., Leisrissa, R., Said, M. D., \& Ohorella, G. (1996). Kerajaan tradisional Sulawesi Tenggara: Kesultanan Buton. Jakarta: Proyek Inventarisasi dan Dokumentasi Sejarah Nasional.

\section{About the Authors}

1. Mohammad Syawaludin, obtained his Doctoral Degree from Gadjah Mada University, Indonesia, in 2015. The author is an Associate Professor at the Department of History of Islamic Civilization, Faculty of Adab and Humanities, Raden Fatah State Islamic University of Palembang, Indonesia.

E-Mail: mohammadsyawaludin_uin@radenfatah.ac.id.

2. Muhammad Sirajudin Fikri, obtained his Master Degree from Raden Fatah State Islamic University of Palembang, Indonesia, in 2009. The author is an Assistant Professor at the Department of Islamic Politics, Faculty of Adab and Humanities, Raden Fatah State Islamic University of Palembang, Indonesia.

E-Mail: muhsirajuddinfikri_uin@radenfatah.ac.id.

3. Yulion Zalpa, obtained his Master Degree from Gadjah Mada University, Indonesia, in 2016. The author is an Assistant Professor at the Department of Islamic Politics, Faculty of Adab and Humanities, Raden Fatah State Islamic University of Palembang, Indonesia. E-Mail: yulionzalpa_uin@radenfatah.ac.id. 